\title{
Pengaruh Pemberian Media Booklet Terhadap Perilaku Ibu Hamil Yang Kekurangan Energi Kronik (Kek) Di Wilayah Kerja Puskesmas Kuala Kecamatan Kuala Kabupaten Bireuen
}

\author{
Agnes Sry Vera Nababan ${ }^{1}$, Yulita $^{2}$, Wanda Lestari ${ }^{3}$, Rani Suraya $^{4}$, Herviana $^{5}$ \\ 1,2,3,4,5 Institut Kesehatan Helvetia Fakultas Kesehatan Masyarakat Program Studi S1 Gizi \\ verasry89@gmail.com
}

\begin{abstract}
ARTICEL INFO
Accepted :01 Oktober 2021

Approve :04 November 2021

Publish :31 Desember 2021
\end{abstract}

\begin{abstract}
Background: Pregnant women are at risk for Chronic Energy Deficiency (KEK) if they have an Upper Arm Circumference (LILA) $<23.5 \mathrm{~cm}$. The results of the initial survey at the research site revealed that in 2020 data from March to August there were 102 pregnant women with 28 pregnant women experiencing Chronic Energy Deficiency (KEK). Chronic (KEK). This type of research uses an experimental design with a pre-test and post-test design. The population in this study were all pregnant women who experienced Chronic Energy Deficiency (KEK) in the 1st and 2nd trimesters of pregnancy as many as 20 people. The sampling technique used by the researcher is total sampling. The results showed that at the time of the pretest the majority of pregnant women had enough knowledge at the time of the pretest, 13 people (65\%), had a negative attitude 19 people (95\%) and 19 people behaved negatively (95\%), while at the time of the posttest the majority had good knowledge of 18 people (90\%), 18 people (90\%) positively behaved and 18 people (90\%). The conclusion of this study is that there is an effect of giving media booklets on the behavior of pregnant women who are chronically deficient in energy $(K E K)$ with a significant value of 0.000 ( $p<0.05)$. Suggestions are expected for respondents to increase knowledge about Chronic Energy Deficiency (KEK) in pregnant women through electronic media and print media, and attend regularly when there are counseling meetings or posyandu
\end{abstract}

Keywords: Media Booklet, Pregnant Mother Behavior

\begin{abstract}
ABSTRAK
Latar belakang: Ibu hamil berisiko mengalami Kekurangan Energi Kronik (KEK) jika memiliki Lingkar Lengan Atas (LILA) $<23,5 \mathrm{~cm}$. Hasil survei awal pada tempat penelitian diketahui bahwa pada tahun 2020 data bulan Maret sampai dengan Agustus terdapat 102 orang ibu hamil dengan 28 ibu hamil mengalami Kekurangan Energi Kronik (KEK).Tujuan penelitian untuk mengetahui bagaimana pengaruh pemberian media booklet terhadap perilaku ibu hamil yang Kekurangan Energi Kronik (KEK). Jenis penelitian ini menggunakan desain experiment dengan rancangan pre-test and post-test design. Populasi dalam Penelitian ini adalah seluruh ibu hamil yang mengalami Kekurangan Energi Kronis (KEK) pada usia kehamilan trimester 1 dan 2 sebanyak 20 orang. Teknik pengambilan sampel yang digunakan peneliti adalah total sampling. Hasil penelitian menunjukkan bahwa pada saat pretest mayoritas pengetahuan ibu hamil pada saat pretest cukup 13 orang $(65 \%)$, bersikap negatif 19 orang (95\%) dan berperilaku negatif 19 orang $(95 \%)$, sedangkan pada saat posttest mayoritas berpengetahuan baik 18 orang $(90 \%)$, bersikap positif 18 orang $(90 \%)$ dan berperilaku positif 18 orang (90\%). Kesimpulan dari Penelitian ini yaitu ada Pengaruh Pemberian Media Booklet Terhadap Perilaku Ibu Hamil Yang Kekurangan Energi Kronik (KEK) dengan nilai signifikan 0,000 ( $p<0,05)$. Saran diharapkan bagi responden agar dapat menambah pengetahuan tentang Kekurangan Energi Kronik
\end{abstract}


(KEK) pada ibu hamil melalui media elektronik maupun media cetak, dan menghadiri secara rutin bila ada pertemuan penyuluhan ataupun posyandu.

\section{Kata Kunci : Media Booklet, Perilaku Ibu Hamil}

\section{PENDAHULUAN}

Status gizi merupakan aspek penting untuk menentukan seorang ibu dapat melewati masa kehamilannya dengan baik atau tidak. Status gizi ibu hamil haruslah normal, karena ketika ibu hamil tersebut mengalami gizi kurang atau gizi berlebih akan banyak komplikasi yang mungkin terjadi selama kehamilan dan berdampak pada kesehatan janin yang dikandungnya. Salah satu permasalahan gizi ibu hamil adalah Kekurangan Energi Kronik (KEK). Bila ibu mengalami hal tersebut, maka akan menimbulkan masalah baik pada ibu maupun janin. Wanita hamil berisiko mengalami Kekurangan Energi Kronik (KEK) jika memiliki Lingkar Lengan Atas (LILA) $<23,5 \mathrm{~cm}$.

Menurut data World Health Organization (WHO) tahun 2015 angka kematian ibu tahun tersebut lebih sedikit dibandingkan angka kematian ibu pada tahun 2014. Hal tersebut ditandai dengan jumlah kematian ibu pada tahun 2014 sebesar 104,7/100.000 Kelahiran Hidup, sedangkan pada tahun 2015 sebesar 87,5/100.000. Pada tahun 2015 target Angka Kematian Ibu (AKI) adalah 70/100.000 Kelahiran Hidup dan program itu telah dilanjutkan Sustainable Development Goals (SDGs), salah satu penyebab masalah Angka Kematian Ibu (AKI) adalah gizi pada ibu hamil seperti Kekurangan Energi Kronik (KEK) (1). Permasalahan Kekurangan Energi Kronik (KEK) ini telah dialami oleh hampir semua negara khususnya di negara-negara berkembang seperti Bangladesh, India, Indonesia, Myanmar, Nepal, Srilangka dan Thailand, prevalensi wanita yang mengalami Kekurangan Energi Kronik (KEK) adalah $15-47 \%$. Hal ini terjadi karena sebagian besar wanita yang mengalami kekurangan energi disebabkan karena makanan yang dikonsumsi tidak sesuai dengan kebutuhan mereka (1).

Menurut Pusat Data dan Informasi Kesehatan RI (Infodatin) tahun 2016 di Indonesia, Sekitar 30 juta wanita usia subur menderita kurang energi Kronik (KEK), yang bila hamil dapat meningkatkan risiko melahirkan BBLR. Setiap tahun, diperkirakan sekitar 350 ribu bayi BBLR ( $\leq 2500$ gram), sebagai salah satu penyebab utama tingginya angka gizi kurang dan kematian balita. Pada tahun 2005 terdapat sekitar 5 juta balita gizi kurang; 1,7 juta diantaranya menderita gizi buruk. Pada usia sekolah, sekitar 11 juta anak tergolong pendek sebagai akibat dari gizi kurang pada masa balita (2).

Banyak ibu hamil yang mengalami masalah gizi khususnya gizi kurang seperti Kurang Energi Kronik (KEK). Hasil Survei 
JURNAL KESEHATAN PENA MEDIKA VOL 11 (2) DESEMBER 2021

PENA MEDIKA

FAKULTAS ILMU KESEHATAN UNIVERSITAS PEKALONGAN

http://jurnal.unikal.ac.id/index.php/medika ISSN : 2086-843X

Kesehatan Rumah Tangga (SKRT) tahun 2015 menunjukkan bahwa $51 \%$ ibu hamil yang mengalami Kekurangan Energi Kronik (KEK) mempunyai kecenderungan melahirkan bayi dengan Berat Badan Lahir Rendah (BBLR), lbu hamil yang menderita Kekurangan Energi Kronik (KEK) juga mempunyai resiko kesakitan yang lebih besar terutama pada trimester II dikehamilannya dibandingkan dengan ibu hamil normal (3).

Bayi yang dilahirkan dengan BBLR umumnya kurang mampu meredam tekanan lingkungan yang baru, sehingga dapat berakibat pada terhambatnya pertumbuhan dan perkembangan, bahkan dapat mengganggu kelangsungan hidupnya. Selain itu juga akan meningkatkan resiko kesakitan dan kematian bayi karena rentan terhadap infeksi saluran penafasan dan sebagainya. Negara Myanmar merupakan negara dengan Angka Kematian Bayi (AKB) tertinggi, yaitu 48/1.000 kelahiran hidup, Indonesia 25/1.000 kelahiran hidup. Thailand 11/1.000 kelahiran hidup, Malaysia 6/1.000 kelahiran hidup, Brunei Darusalam 6/1.000 kelahiran hidup, dan yang paling rendah adalah singapur 2/1.000 kelahiran hidup (4).

Berdasarkan penelitian yang dilakukan oleh Nurul Hidayah, dkk yang berjudul karakteristik umur dan paritas ibu hamil dengan Kurang Energi Kronik (KEK) di Puskesmas Kelayan Timur tahun 2015 menunjukkan bahwa dari 72 data yang dijadikan sampel hasil karakteristik ibu hamil Kekurangan Energi Kronik (KEK) berdasarkan umur yaitu $<20$ tahun 13 responden $(18,1 \%), 20-35$ tahun 53 responden $(73,6 \%)$, dan $>35$ tahun 6 responden $(8,3 \%)$, sedangkan karakteristik ibu hamil Kekurangan Energi Kronik (KEK) berdasarkan paritas yaitu primipara 37 responden $(51,4 \%)$, multipara 33 responden $(45,8 \%)$, dan grande multipara2 responden (2,8\%). Maka dapat disimpulkan bahwa umur ibu hamil dengan Kurang Energi Kronik (KEK) yang paling banyak adalah pada usia 20-35 tahun sedangkan berdasarkan paritas paling banyak adalah primipara (5).

Menurut Depkes (2016), masalah gizi kurang dipengaruhi oleh tidak tercukupinya asupan energi, protein, dan zat gizi lain serta adanya infeksi penyakit. Penyebab masalah tersebut didasari oleh kondisi, sosial, ekonomi, budaya keluarga seperti: pola asuh, daya beli, dan pengetahuan ibu. Selain itu, salah satu penyebab masalah gizi adalah kurangnya pengetahuan dan kesadaran gizi masyarakat, meskipun pangan cukup tersedia dan beranekaragam serta mempunyai nilai gizi tinggi. (6).

Masalah gizi merupakan masalah kesehatan masyarakat yang penanggulangannya tidak dapat dilakukan dengan pendekatan medis dan pelayanan kesehatan saja. Masalah gizi lain merupakan sindroma kemiskinan yang erat kaitannya dengan masalah ketahanan pangan di tingkat rumah tangga, juga menyangkut aspek 
pengetahuan dan perilaku yang kurang mendukung pola hidup sehat. Oleh karena itu, gizi merupakan salah satu faktor penentu utama kualitas sumber daya manusia. Gizi buruk tidak hanya meningkatkan angka kesakitan dan kematian, tetapi juga menurunkan produktifitas, menghambat sel-sel pertumbuhan otak yang mengakibatkan kebodohan dan keterbelakangan (7).

Pengetahuan merupakan faktor tidak langsung penyebab Kekurangan Energi Kronik (KEK) pada ibu hamil. Oleh karena itu, berbagai cara dapat dilakukan dalam upaya pencegahan Kekurangan Energi Kronik (KEK), salah satunya dengan pendidikan gizi. Pendidikan gizi dapat menghasilkan peningkatan pada pengetahuan, kesadaran serta perubahan perilaku untuk mencapai kesadaran gizi dan kesehatan yang optimal. Dalam proses pendidikan kesehatan, supaya diperoleh hasil yang efektif dibutuhkan alat bantu atau media pendidikan, seperti misalnya booklet. Fungsi dari alat bantu tersebut adalah untuk menyampaikan informasi kesehatan baik berupa tulisan atau gambar. Booklet memiliki dua keunggulan dibandingkan dengan media lain yaitu dapat dipelajari setiap waktu karena desainnya dalam bentuk buku serta dapat memuat lebih banyak informasi (8).

Penelitian yang dilakukan oleh Tita Rosmawati Dafiu yang berjudul Hubungan Pengetahuan Ibu Hamil Tentang Gizi Kehamilan Dengan Kejadian Kurang Energi
Kronik (KEK) Pada Kehamilan di Kota Yogyakarta tahun 2017. Berdasarkan hasil penelitian, kurangnya pengetahuan ibu hamil tentang gizi menyebabkan kurangnya makanan bergizi sela hamil. Salah satu faktor yang mempengaruhi gizi ibu hamil yaitu pengetahuan ibu hamil dan keluarga tentang zat gizi dalam makanan. Perencanaan dan penyusunan makanan kaum ibu atau wanita dewasa mempunyai peranan yang penting. Faktor yang mempengaruh perencanaan dan penyusunan makanan yang sehat dan seimbang bagi ibu hamil yaitu kemampuan ibu dan keluarga dalam membeli makanan serta pengetahuan tentang gizi. Pengetahuan yang dimiliki seorang ibu akan mempengaruhi perilaku ibu termasuk dalam pengambilan keputusan. Ibu dengan gizi yang baik, kemungkinan akan memenuh kebutuhan gizi yang baik untuk bayinya. Sehingga ibu yang memiliki pengetahuan yang baik meskipun pada awal kehamilannya mengalami mual dan rasa tidak nyaman maka ia akan berupaya untuk memenuhi kebutuhan gizinya dan juga bayinya (9).

Tujuan Peneliti adalah untuk mengetahui bagaimana pengaruh pemberian media booklet terhadap perilaku ibu hamil di Wilayah Kerja Puskesmas Kuala Kecamatan Kuala Kabupaten Bireuen tahun 2020

\section{METODE PENELITIAN}


Penelitian menggunakan desain experiment dengan rancangan pre-test and post-test design. Intervensi yang diberikan kepada responden berupa pemberian booklet dan kuesioner yang tujuan untuk mengetahui pengaruh pemberian media booklet terhadap perilaku ibu hamil di Wilayah Kerja Puskesmas Kuala Kecamatan Kuala Kabupaten Bireuen . Penelitian ini dilakukan di Wilayah Kerja Puskesmas Kuala Kecamatan Kuala Kabupaten Bireuen. Penelitian ini dilakukan selama 15 hari pada tanggal 2 sampai dengan 17 Desember tahun 2020. Populasi adalah keseluruhan subjek penelitian. Populasi dalam penelitian ini adalah seluruh ibu hamil yang mengalami Kekurangan Energi Kronis (KEK) pada usia kehamilan trimester 1 dan 2 diwilayah kerja. Puskesmas Kuala Kecamatan Kuala Kabupaten Bireuen yaitu sebanyak 20 orang. Sampel merupakan bagian dari populasi yang dipilih dengan cara tertentu untuk bisa memenuhi atau mewakili populasi (10). Adapun teknik pengambilan sampel menggunakan total sampling yaitu teknik pengambilan sampel dimana jumlah sampel sama dengan populasi yang berjumlah 20 orang ibu hamil yang mengalami Kekurangan Energi Kronis (KEK). Analisa data diolah dengan menggunakan komputer dengan analisa univariat dan analisis bivariat

\section{HASIL DAN PEMBAHASAN}

\section{Karakteristik Reponden}

Dari hasil penelitian yang dilakukan oleh penulis mengenai“Pengaruh pemberian media booklet terhadap perilaku ibu hamil di Wilayah Kerja Puskesmas Kuala Kecamatan Kuala Kabupaten Bireuen", terhadap ibu hamil pada usia kehamilan trimester 1 dan 2 pada bulan Juli sampai dengan Desember 2020 yaitu sebanyak 20 orang. Maka diperoleh karakteristik responden sebagai berikut

Tabel 1. Distribusi Frekuensi Karakteristik Responden ibu hamil yang mengalami Kekurangan Energi Kronik (KEK) di Wilayah Kerja Puskesmas Kuala Kecamatan Kuala Kabupaten Bireuen

\begin{tabular}{lccc}
\hline & Umur & Jumlah (n) & Persentase (\%) \\
\hline $17-25$ tahun & & 1 & 5 \\
$26-35$ tahun & Alamat & $\mathbf{2 0}$ & 95 \\
\hline Total & & $\mathbf{1 0 0}$ \\
\hline \multicolumn{1}{c}{ Cot Unoe } & 1 & 5 \\
Kuta Baroe & 1 & 5 \\
Krueng Juli Timu & 1 & 5 \\
Krueng Juli Barat & 1 & 5 \\
Cot Trieng & 2 & 10 \\
Cot U Sibak & 2 & 10 \\
Kuala Raja & 1 & 5 \\
Ujong Blang & 2 & 10
\end{tabular}




\begin{tabular}{lcc} 
Weujangka & 2 & 10 \\
Lhok Awe-Awe & 1 & 5 \\
Cot batee & 1 & 5 \\
Cot Lagasawa & 2 & 10 \\
Lancok Pante Ara & 2 & 10 \\
Ujong Blang Mesjid & 1 & 5 \\
\hline Total & $\mathbf{2 0}$ & $\mathbf{1 0 0}$ \\
\hline Pendidikan & & 80 \\
\hline SMA & 16 & 20 \\
Sarjana & 4 & $\mathbf{1 0 0}$ \\
\hline Total & $\mathbf{2 0}$ & 65 \\
\hline Pekerjaan & & 20 \\
\hline IRT & 13 & 15 \\
\hline Wirausaha & 4 & $\mathbf{1 0 0}$ \\
PNS & 3 & \\
\hline Total & $\mathbf{2 0}$ & 30 \\
\hline Urutan Kehamilan & & 55 \\
\hline 1 & 6 & 15 \\
2 & 11 & $\mathbf{1 0 0}$ \\
\hline 2 & 3 & 100 \\
\hline Total & $\mathbf{2 0}$ & 0 \\
\hline Ukuran LILA & & $\mathbf{1 0 0}$ \\
\hline$<23,5$ & 20 & \\
\hline T23,5 & 0 & $\mathbf{2 0}$ \\
\hline Total & & \\
\hline
\end{tabular}

Sumber: Data primer Tahun 2020

2. Pengetahuan Ibu Hamil Yang Mengalami Kekurangan Energi Kronik (KEK)

Tabel 2. Distribusi Frekuensi pengetahuan ibu hamil yang mengalami Kekurangan Energi Kronik (KEK) di Wilayah Kerja Puskesmas Kuala Kecamatan Kuala Kabupaten Bireuen

\begin{tabular}{cccccc}
\hline \multirow{2}{*}{ No } & \multirow{2}{*}{ Pengetahuan } & \multicolumn{2}{c}{ Pretest } & \multicolumn{2}{c}{ Posttest } \\
\cline { 2 - 6 } & & Jumlah & \% & Jumlah & $\%$ \\
\hline 1 & Baik & 1 & 5 & 18 & 90 \\
2 & Cukup & 13 & 65 & 2 & 10 \\
3 & Kurang & 6 & 30 & 0 & 0 \\
\hline \multicolumn{2}{r}{ Total } & $\mathbf{2 0}$ & $\mathbf{1 0 0}$ & $\mathbf{2 0}$ & $\mathbf{1 0 0}$ \\
\hline
\end{tabular}

Sumber: Data primer Tahun 2020

Berdasarkan tabel diatas, dapat dilihat bahwa distribusi frekuensi pengetahuan ibu hamil yang mengalami Kekurangan Energi Kronik (KEK) di Wilayah Kerja Puskesmas Kuala Kecamatan Kuala Kabupaten Bireuen, dari 20 responden pada hasil pretest yang berpengetahuan baik 1 orang (5\%), cukup 13 orang (65\%) dan kurang 6 orang (30\%), sedangkan pada hasil posttest yang berpengetahuan baik 18 orang (90\%) dan cukup 2 orang (10\%).

3. Sikap Ibu Hamil Yang Mengalami Kekurangan Energi Kronik (KEK) 
Tabel 3. Distribusi Frekuensi Sikap Ibu Hamil yang Mengalamia Kekurangan Energi Kronik (KEK) di Wilayah Kerjaa Puskesmas Kuala Kecamatan Kuala Kabupaten Bireuen

\begin{tabular}{cccccc}
\hline \multirow{2}{*}{ No } & \multirow{2}{*}{ Sikap } & \multicolumn{2}{c}{ Pretest } & \multicolumn{2}{c}{ Posttest } \\
\cline { 3 - 6 } & & Jumlah & $\mathbf{\%}$ & Jumlah & \% \\
\hline 1 & Positif & 1 & 5 & 18 & 90 \\
2 & Negatif & 19 & 95 & 2 & 20 \\
\hline & Total & $\mathbf{2 0}$ & $\mathbf{1 0 0}$ & $\mathbf{2 0}$ & $\mathbf{1 0 0}$ \\
\hline
\end{tabular}

Sumber: Data primer Tahun 2020

Berdasarkan tabel diatas, dapat dilihat bahwa distribusi frekuensi sikap ibu hamil yang mengalami Kekurangan Energi Kronik (KEK) di Wilayah Kerja Puskesmas Kuala Kecamatan Kuala Kabupaten Bireuen, dari 20 responden pada hasil pretest yang bersikap positif 1 orang (5\%) dan negatif 19 orang (95\%), sedangkan pada hasil posttest yang bersikap positif 18 orang $(90 \%)$ dan negatif 2 orang $(20 \%)$

4. Perilaku Ibu Hamil Yang Mengalami Kekurangan Energi Kronik (KEK)

Tabel 4 Distribusi Frekuensi Perilaku Ibu Hamil yang Mengalamia Kekurangan Energi Kronik (KEK) di Wilayah Kerjaa Puskesmas Kuala Kecamatan Kuala Kabupaten Bireuen

\begin{tabular}{cccccc}
\hline \multirow{2}{*}{ No } & \multirow{2}{*}{ Perilaku } & \multicolumn{2}{c}{ Pretest } & \multicolumn{2}{c}{ Posttest } \\
\cline { 3 - 6 } & & Jumlah & $\mathbf{\%}$ & Jumlah & \% \\
\hline 1 & Positif & 1 & 5 & 18 & 90 \\
2 & Negatif & 19 & 95 & 2 & 20 \\
\hline & Total & $\mathbf{2 0}$ & $\mathbf{1 0 0}$ & $\mathbf{2 0}$ & $\mathbf{1 0 0}$ \\
\hline
\end{tabular}

Sumber: Data primer Tahun 2020

Berdasarkan tabel diatas, dapat dilihat bahwa distribusi frekuensi sikap ibu hamil yang mengalami Kekurangan Energi Kronik (KEK) di Wilayah Kerja Puskesmas Kuala Kecamatan Kuala Kabupaten Bireuen, dari 20 responden pada hasil pretest yang berperilaku positif 1 orang (5\%) dan negatif 19 orang (95\%), sedangkan pada hasil posttest yang berperilaku positif 18 orang $(90 \%)$ dan negatif 2 orang $(20 \%)$. 
JURNAL KESEHATAN PENA MEDIKA VOL 11 (2) DESEMBER 2021

PENA MEDIKA

FAKULTAS ILMU KESEHATAN UNIVERSITAS PEKALONGAN

http://jurnal.unikal.ac.id/index.php/medika ISSN : 2086-843X

5. Pengaruh pemberian booklet terhadap pengetahuan ibu hamil yang mengalami Kekurangan Energi Kronik (KEK)

Tabel 5. Pengaruh pemberian booklet terhadap pengetahuan ibu hamil yang mengalami Kekurangan Energi Kronik (KEK) di Wilayah Kerja Puskesmas Kuala Kecamatan Kuala Kabupaten Bireuen

Paired Samples Test

Paired Differences

\begin{tabular}{|c|c|c|c|c|c|c|c|c|c|}
\hline & & \multirow[t]{2}{*}{ Mean } & \multirow{2}{*}{$\begin{array}{l}\text { Std. } \\
\text { Deviat } \\
\text { ion }\end{array}$} & \multirow{2}{*}{$\begin{array}{l}\text { Std. } \\
\text { Error } \\
\text { Mean }\end{array}$} & \multicolumn{2}{|c|}{$\begin{array}{l}95 \% \text { Confidence } \\
\text { Interval of the } \\
\text { Difference }\end{array}$} & \multirow[t]{2}{*}{$\mathrm{t}$} & \multirow[t]{2}{*}{$\mathrm{df}$} & \multirow[t]{2}{*}{$\begin{array}{l}\text { Sig. (2. } \\
\text { tailed) }\end{array}$} \\
\hline & & & & & Lower & Upper & & & \\
\hline $\begin{array}{l}\text { Pair } \\
1\end{array}$ & $\begin{array}{l}\text { ptahuan_1 - } \\
\text { ptahuan_2 }\end{array}$ & -1.150 & .489 & .109 & -1.379 & -.921 & -10.510 & 19 & \\
\hline $\begin{array}{l}\text { Pair } \\
2\end{array}$ & $\begin{array}{l}\text { sikap_1 - } \\
\text { sikap_2 }\end{array}$ & -.850 & .366 & .082 & -1.021 & -.679 & -10.376 & 19 & .000 \\
\hline $\begin{array}{l}\text { Pair } \\
3\end{array}$ & $\begin{array}{l}\text { perilaku_1 - } \\
\text { perilaku_2 }\end{array}$ & -.850 & .366 & .082 & -1.021 & -.679 & -10.376 & 19 & \\
\hline
\end{tabular}


Berdasarkan tabel diatas, dapat dilihat bahwa Paired Samples Test menunjukkan nilai korelasi yang menunjukkan hubungan kedua variabel pada sampel berpasangan. Hal ini diperoleh nilai signifikansi (2-tailed) adalah $0,000(\mathrm{p}<0.05)$. Sehingga hasil pretest dan posttes mengalami perubahan yang signifikan (berarti). Berdasarkan statistika tersebut dapat disimpulkan adanya pengaruh pemberian booklet terhadap perilaku ibu hamil yang mengalami Kekurangan Energi Kronik (KEK) di Wilayah Kerja Puskesmas Kuala Kecamatan Kuala Kabupaten Bireuen.

Pada penelitian ini, dapat dilihat bahwa berdasarkan analisis bivariat distribusi frekuensi perilaku ibu hamil yang mengalami Kekurangan Energi Kronik (KEK) di Wilayah Kerja Puskesmas Kuala Kecamatan Kuala Kabupaten Bireuen dapat dilihat bahwa Paired Samples Test menunjukkan nilai korelasi yang menunjukkan hubungan kedua variabel pada sampel berpasangan. Hal ini diperoleh nilai signifikansi (2-tailed) adalah 0,000 ( $\mathrm{p}<0.05)$. Sehingga hasil pretest dan posttes mengalami perubahan yang signifikan (berarti). Berdasarkan statistika tersebut dapat disimpulkan adanya pengaruh pemberian booklet terhadap perilaku ibu hamil yang mengalami Kekurangan Energi Kronik (KEK) di Wilayah Kerja Puskesmas Kuala Kecamatan Kuala Kabupaten Bireuen.

Menurut pendapat peneliti salah satu faktor yang menentukan perilaku tentang kesehatan seseorang adalah pengetahuan dan sikap, semakin tinggi pengetahuan dan sikap, akan mendukung seseorang untuk berperilaku positif, begitu pula sebaliknya. Jika ditinjau dari pengetahuan ibu yang kurang dan sikap ibu negatif. Maka ibu yang berperilaku negatif karena tidak melakukan gizi dengan baik yang merupakan hal yang penting bagi kebutuhan gizi selama hamil, sebaliknya ibu berperilaku positif karena ibu menganggap gizi itu penting sehingga ibu mau melakukan sadar gizi dengan baik.

Perilaku merupakan salah satu faktor yang menyebabkan Kekurangan Energi Kronik (KEK) secara tidak langsung pada ibu hamil. Perilaku yang tidak baik pada ibu hamil disebabkan oleh kurangnya informasi penting seperti asupan makanan dan kandungan gizi yang harus dikonsumsi selama masa kehamilan (11).

Dari pembahasan diatas, telah diuraikan bahwa penyebab ibu hamil mengalami Kekurangan Energi Kronik (KEK) karena pengaruh pengetahuan, sikap dan perilaku. Namun dapat diketahui bahwa selain 3 variabel tersebut ada hal lain yang menyebabkan ibu hamil mengalami Kekurangan Energi Kronik (KEK) diantaranya terjadi hiperemisis pada awal usia kehamilan (trimister I), perubahan hormonal menyebabkan ibu mengalami mual muntah sehingga nafsu makan dan berat badan ibu hamil menurun (11). 
Selain itu, di beberapa daerah adanya budaya pantangan makan seperti durian karena jika durian di konsumsi dalam jumlah banyak atau terlalu sering dikhawatirkan menimbulkan keluhan perut kembung karena durian merupakan buah bergas tinggi.Selain itu durian memiliki kadar gula dan lemak tinggi yang jika dikonsumsi berlebihan beresiko menyebabkan bayi besar, dan mengandung asam arachidonat yang merangsang kontraksi dan menyebabkan mual muntah pada ibu hamil.

Pantangan pepaya muda karena terdapat getah yang dapat menyebabkan kontraksi pada dinding rahim. Ibu hamil harus menjauhi buah yang berwarna hijau ini apalagi pada usia kehamilan sudah memasuki trimester akhir. Namun, ibu hamil boleh memakan pepaya yang telah matang dan berwarna oranye. Pastikan untuk selalu mencuci dan mengupasnya hingga bersih. Pantangan nanas karena nanas terkandung enzim bromelain yang menyebabkan pelunakan pada leher rahim, adapun enzim ini sama dengan jenis enzim papain yang biasanya terkandung dalam buah pepaya muda. Jenis enzim tersebut berbahaya karena dapat mengakibatkan keguguran pada usia hamil muda dan juga persalinan dini atau bayi lahir premature dan pantangan tape karena terbuat dari proses fermentasi singkong dengan ragi, sebenarnya semua jenis makanan yang dibuat melalui proses fermentasi dapat mengganggu kesehatan ibu hamil dan janin. terlebih lagi tape juga mengandung alcohol (1).

\section{KESIMPULAN}

Ada Pengaruh pemberian media booklet terhadap perilaku ibu hamil di Wilayah Kerja Puskesmas Kuala Kecamatan Kuala Kabupaten Bireuen dengan nilai signifikansi (2-tailed) adalah 0,000 $(\mathrm{p}<0.05)$

\section{SARAN}

Diharapkan bagi responden agar dapat menambah pengetahuan tentang Kekurangan Energi Kronik (KEK) pada ibu hamil melalui media elektronik maupun media cetak, dan menghadiri secara rutin bila ada pertemuan penyuluhan ataupun posyandu .

\section{DAFTAR PUSTAKA}

Ri K Kesehatan. Infodatin Pusat Data Dan Informasi Kementrian Kesehatan Ri. In: Ri K Kesehatan, Editor. Kementrian Kesehatan $\mathrm{Ri}$ [Internet]. Kementrian. Jakarta: Kementrian Kesehatan Ri, Pusat Data Dan Informasi; 2014. P. 8. Available From: Www.Kementriankesehatanri.Com

Ri Kk. Infodatin: Pusat Data Dan Informasi Kementerian Kesehatan Ri. In: Ri K Kesehatan, Editor. Kementrian Kesehatan Ri [Internet]. Kementrian. Jakarta: Kementrian Kesehatan; 2016. P. 10. Available From: Infodatin

Raisyah Utami D. Studi Pelaksanaan Program 
Keluarga Sadar Gizi (Kadarzi) Di Puskesmas Pangkajene Kabupaten Sidrap. J Kesehat [Internet]. 2015;1(Sadar Gizi):112. Available From: (Ichasmansa@Ymail.Com,Dedhymks@Ya hoo.Com,Salam_Skm01@Yahoo.Com,085 299277317)

Wachidah U, Arifin S, Hidayah N. Karakteristik Umur Dan Paritas Ibu Hamil Dengan Kurang Energi Kronik (Kek) Di Puskesmas Kelayan Timur Tahun 2015. J Kesehat [Internet]. 2016;1(Kek Pada Ibu Hamil):9. Available From: Google Scholar

Linda. Penyebab Kejadian Kekurangan Energi Kronis Puskesmas Jelbuk Jember Incidence In High-Risk Pregnant Women And Utilization Of Antenatal Care In Jelbuk Public Health Center Jember District. J Kesehat [Internet]. 2018;6(2):136-42. Available From: E-Mail: Christyana_Sandra@Yahoo.Com

Maryam S. Gizi Dalam Kesehatan Reproduksi [Internet]. 1st Ed. Hafni, Editor. Salemba Medika. Yogyakarta: Selemba Medika; 2016. 230 P. Available From: Www.Selemba Medika.Com

Suhaimi A. Pangan , Gizi Dan Kesehatan. In: Royensyah R Van, Editor. Deepunlish [Internet]. Azwar Saih. Sleman: Deepunlish; 2019. P. 197. Available From: Www.Deepublish.Co.Id

Yulianasari P, Nugraheni Sa, Kartini A. Pengaruh Pendidikan Gizi Dengan Media Booklet Terhadap Perubahan Perilaku Remaja Terkait Pencegahan Kekurangan Energi Kronis (Studi Pada Remaja Putri Sma Kelas Xi Di Sma Negeri 14 Dan Sma Negeri 15 Kota Semarang). J Kesehat [Internet]. 2019;7(4):420-8. Available From: E-Mail: Prastikays@Gmail.Com

Dafiu Tr, Studi P, Iv D, Kebidanan J, Yogyakarta Pk. Hubungan Pengetahuan Ibu Hamil Tentang Gizi Kehamilan Dengan Kejadian Kurang Energi Kronik (Kek) Pada Kehamilan Di Kota Yogyakarta Tahun 2017. J Kesehat [Internet].
2017;1(Kesehatan):82. Available From: Google Scholar

Indra Im. Cara Mudah Memahami Metodologi Penelitian. In: Cahyaniungrum I, Editor. $\mathrm{Cv}$ Budi Utama [Internet]. 1st Ed. Sleman: $\mathrm{Cv}$ Budi Utama; 2019. P. 84. Available From: Www.Deepublish.Co.Id

Betty Y. Buku Pegangan Tugas Kua Sebagai Konselor 100 Dalam Edukasi Calon. In: Nabila Ad, Editor. Cv Budi Utama [Internet]. 1st Ed. Sleman: Cv Budi Utama; 2019. P. 400. Available From: Www.Deepulish.Co.Id

Pipit Festi W. Buku Ajar Gizi Dan Diet. In: Safawi R Dwi, Editor. Um Surabaya [Internet]. 1st Ed. Surabaya: Um Surabaya; 2018. P. 229. Available From: Http://Www.P\#I.Um-Surabaya.Ac.Id 